\title{
Identification of Erwinia rhapontici as the Causal Agent of Crown and Shoot Rot and Pink Seed of Pea in Nebraska
}

\begin{abstract}
Anthony O. Adesemoye, Department of Plant Pathology, West Central REC, University of Nebraska, North Platte 69101; Hsin-Ho Wei, Department of Plant Pathology, West Central REC, University of Nebraska, North Platte 69101; and Robert M. Harveson, Panhandle Research and Extension Center, University of Nebraska, Scottsbluff 69361
\end{abstract}

Accepted for publication 2 June 2016. Published 6 July 2016.

Adesemoye, A. O., Wei, H.-H., and Harveson, R. M. 2016. Identification of Erwinia rhapontici as the causal agent of crown and shoot rot and pink seed of pea in Nebraska. Plant Health Prog. 17:155-157.

Over the last five years, the production of dry yellow peas (Pisum sativum L.) has been increasing in Nebraska and other areas of the Central High Plains, according to a USDA report (Jasa 2013). Dry pea is a short-season crop with a low water requirement, making it a good rotational crop for the high plains. We have noted bacterial pathogens, potentially a disease complex, that may negatively impact the production of pea in this region, and one of the emerging pathogens is Erwinia rhapontici. This pathogen is a gram-negative bacterium that has been reported from soil, seed, and different plant tissues, causing pink seed, crown rot, shoot and stem rot, blossom rot, or soft rot on more than 20 plant hosts, including pea (Huang et al. 2003). The disease was first reported on pea in the United States from Montana in 2002 and was later found in North Dakota in 2006 (Wise et al. 2008). Erwinia rhapontici belongs to the carotovora subgroup of Erwinia. Unlike many members of the soft rot carotovora subgroup that produces pectolytic enzyme, $E$. rhapontici does not degrade pectate. The organism is capable of fermenting glucose, fructose, maltose, and sucrose. Also, it produces a diffusible pink pigment on sucrose-peptone agar but not on potato dextrose agar nor nutrient agar. However, it has been shown that some strains may not produce pink pigments regardless of the type of media used (Huang et al. 2003). Proferrosamine A has been identified in the pink pigment produced, it is associated with iron deficiency in plants, and was suspected by Huang et al. (2003) as partly a pathogenicity determinant and virulence factor of $E$. rhapontici.

\section{SYMPTOMS AND DISEASE SITUATION IN 2015 IN NEBRASKA}

Due to the increased pea acreage in Nebraska, we have conducted a disease survey from production counties over the last three years to proactively identify potential disease problems in the state. During the 2015 season, in one specific, irrigated field in Custer County, NE, a high incidence of plants (Fig. 1) exhibiting bacterial-like symptoms in the root, crown, and shoot was noted (Fig. 2, left and right).

The symptoms included wilted leaves that remained attached to the stem, rot of root and crown, brown to pinkish discoloration of

Corresponding author: Tony Adesemoye. Email: tony.adesemoye@unl.edu.

doi:10.1094/PHP-BR-15-0056

(C) 2016 The American Phytopathological Society the crown and part of stem, and pinkish lesions on pods (Fig. 3, left and right).

\section{SAMPLE COLLECTION, ISOLATION, AND IDENTIFICATION}

Samples with crown and root rot symptoms were collected in Custer County, NE. The samples were transported on ice to the laboratory at the University of Nebraska WCREC North Platte. Margins of symptomatic tissues of the tap roots, lateral roots, crown/basal stems, and pods were cut with a sterile scalpel, rinsed with deionized water, dried with paper towels, dipped in $95 \%$ ethanol for $3 \mathrm{~s}$, and briefly flamed. About six pieces of 2-mm ${ }^{2}$ sections were placed onto tryptic soy agar (TSA) and incubated at $22 \pm 1{ }^{\circ} \mathrm{C}$. Resulting bacterial cultures were purified by serial transfer of isolates. The pure bacterial cultures were also transferred to sucrose peptone agar (SPA) with some showing pinkish coloration in colonies. A total of seven bacterial strains were stored for long-term storage in $1 \mathrm{ml}$ of tryptic soy broth containing $20 \%$ glycerol and maintained in a $-80^{\circ} \mathrm{C}$ freezer for further identification. Four of the isolates which were later identified as Erwinia rhapontici did not grow at $37^{\circ} \mathrm{C}$ and tested positive to fermentation of glucose, fructose, maltose, and sucrose.

Molecular identification of strains was done by sequencing the 16S rRNA using 27F/1492R primer set (Galkiewicz and Kellogg 2008). Polymerase chain reaction (PCR) was performed in a ThermalCycler (Bio-Rad Laboratories, Inc., Hercules, CA). The

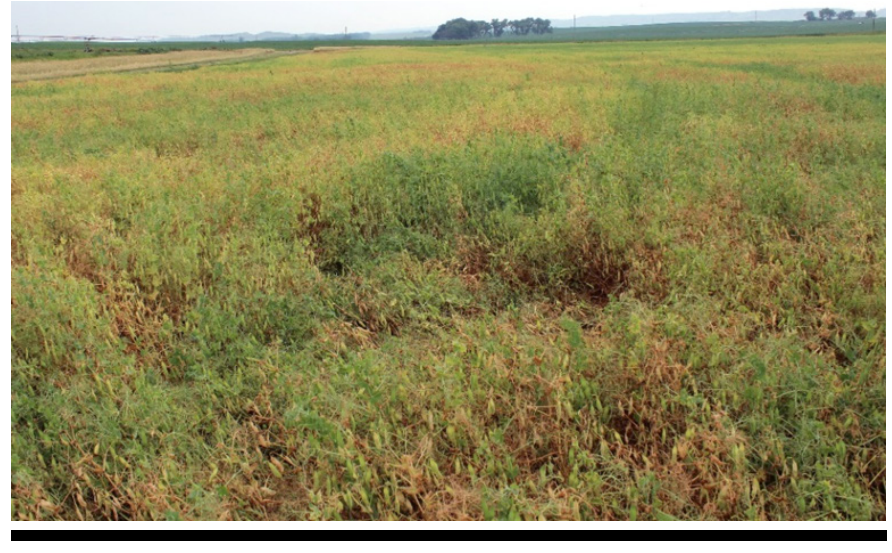

FIGURE 1

A field with high incidence and severity from bacterial disease in Nebraska in 2015. 
25- $\mu$ l PCR reaction contained $12.5 \mu 1$ of GoTaq Green Master Mix (Promega, Madison, WI), $9.3 \mu \mathrm{l}$ of PCR-grade water, $0.6 \mu \mathrm{l}$ of $10 \mu \mathrm{M}$ of each primer set, and $2 \mu \mathrm{DNA}$ templates. The PCR products were verified using $1 \%$ agarose gel and quality checked using NanoDrop Spectrophotometer after it was purified.

Sequencing was done at the Institute for Integrative Genome Biology of the University of California Riverside (UCR). The sequence analyses were performed and the sequences of the 7 strains have been deposited in the GenBank. They included four strains of Erwinia rhapontici (described above), two strains of Pseudomonas fluorescens, and one strain of Enterobacter sp. The Accession Nos. are KU312046 to KU312052 for the 16S rRNA.

\section{PATHOGENICITY TESTING: ROLLED TOWEL AND GREEN- HOUSE ASSAYS}

Identified strains were tested for pathogenicity using the rolledtowel assay (Ellis et al. 2011). Each strain was incubated in tryptic soy broth for 24 to $36 \mathrm{~h}$ to achieve a concentration of about $1 \times 10^{8} \mathrm{cfu} / \mathrm{ml}$, centrifuged and the concentrated cells were

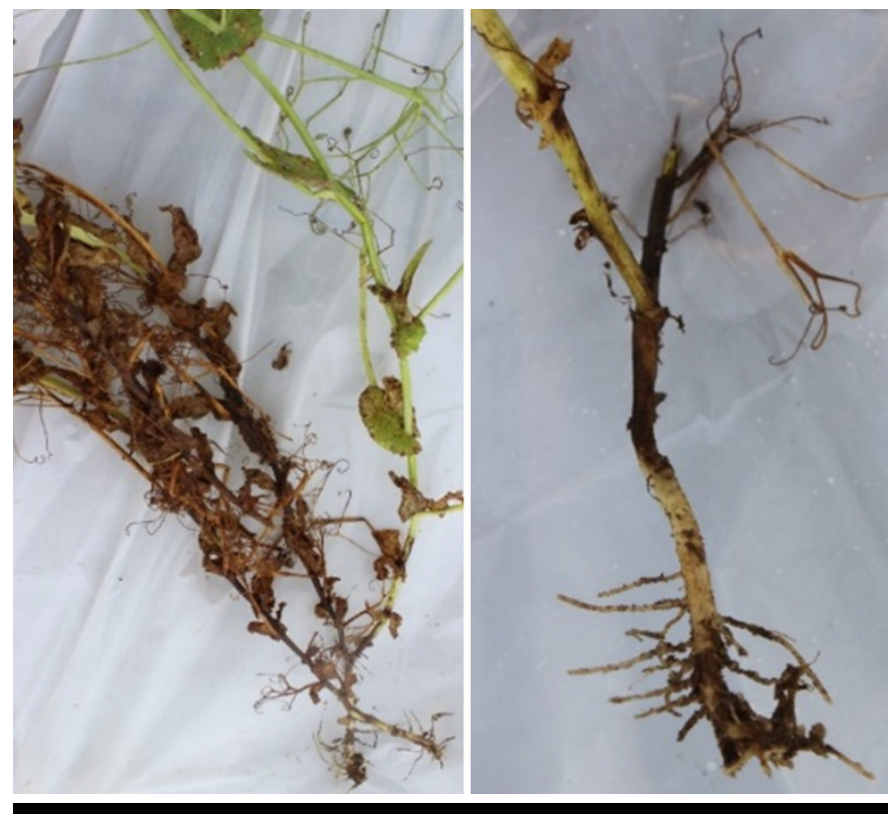

\section{FIGURE 2}

Symptoms (left) on root, crown rot, and shoot, and a close up (right) of the stem, crown, and root.

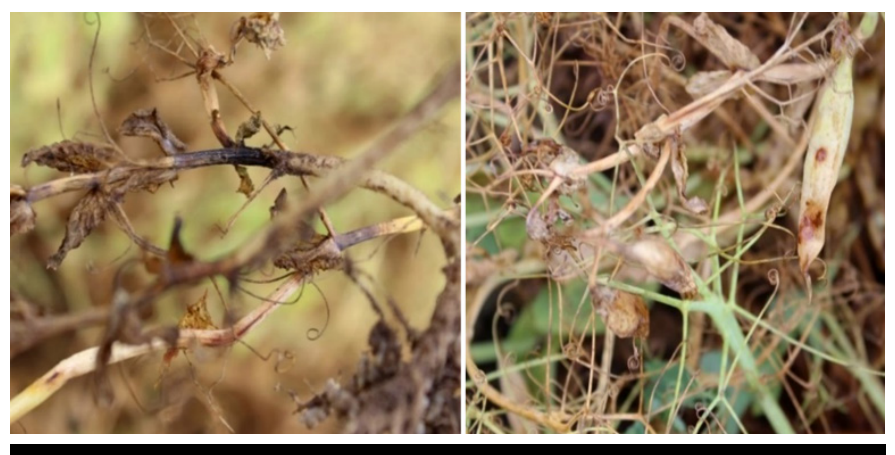

FIGURE 3

Bacterial lesions on leaves, stem, and pods: (left) wilted and dry leaves that remained attached to the stem; and (right) several tissues showing pink to pinkish-brown color lesions, including pods, stem, and crown. re-suspended in sterile distilled water. Eight pea seeds were soaked in the suspension for $30 \mathrm{~min}$, the seeds were removed and set in a row on moistened paper towel, another moistened paper towel was placed on top, and they were rolled together with the seeds. Two additional replicates were prepared and incubated in the growth chamber at $26 \pm 1{ }^{\circ} \mathrm{C}$ and $75 \%$ relative humidity with a 12-h photoperiod for 7 days. Subsequently, only seedlings inoculated with each of the four Erwinia rhapontici strainsA527, A533, A534, and A535-exhibited typical symptoms similar to those originally observed in the field but no such symptoms on seedlings inoculated with Enterobacter sp., Pseudomonas fluorescens, or sterile distilled water. Some of the seeds and roots inoculated with the pathogens showed pinkish discoloration as could be seen in the arrows (Fig. 4). Previous studies have linked the discoloration to ferrorosamines, a watersoluble pigment (Huang et al. 2007).

Further tests were conducted in the greenhouse by soaking seeds in a bacterial suspension prepared in a similar manner as explained for the rolled towel assay. Pea seeds were soaked in the bacterial suspension for $30 \mathrm{~min}$ before 4 seeds were planted per pot in a $15-\mathrm{cm}$-diameter plastic pot. Seedlings were allowed to grow in the greenhouse at $22 \pm 4^{\circ} \mathrm{C}$ with 4 replicate pots per treatment. Seedlings from seeds inoculated with the $4 E$. rhapontici strains exhibited symptoms seen on the field while the control did not (Fig. 5). The pathogens were recovered from symptomatic plants, thus fulfilling Koch's postulates.

\section{CONCLUSION}

This is the first report of Erwinia rhapontici on pea from Nebraska. Comprehensive studies should be conducted to understand the distribution and epidemiology of this pathogen and its role in the potentially bacterial complex in Nebraska and across the Great Plains. This is an important factor to consider, particularly with the increasing pea acreage in the region. Furthermore, prior reports have demonstrated that E. rhapontici could be seed-transmitted to neighboring crops of wheat and dryedible bean, if the crops were injured at the early pod formation stage (Huang et al. 2007). Although, wheat has been the primary

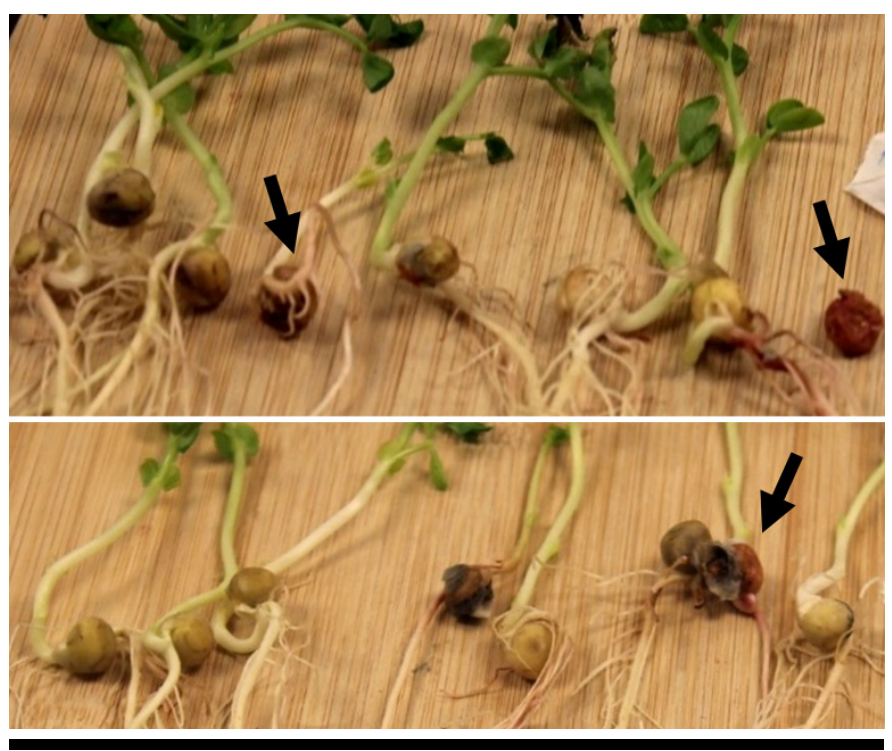

FIGURE 4

Rolled towel assay to test the pathogenicity of strains: (top) symptoms from a mixture of four Erwinia rhapontici strains-A527, A533, A534, and A535; and (bottom) similar symptoms from a single strain.. 
crop rotated with pea under rain-fed conditions in western Nebraska, other potential hosts of this pathogen grown in rotation with wheat in this area include dry bean, chickpeas, and lentils (Hsieh et al. 2010). Lastly, minimum tillage practices have

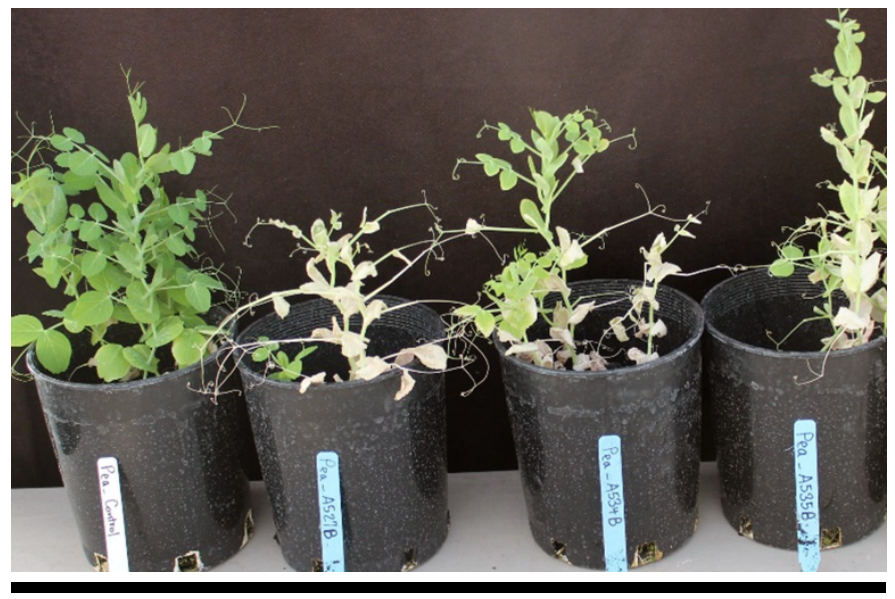

FIGURE 5

Greenhouse pathogenicity testing: healthy control on the left and strains A527, A534, and A535 to the right. dramatically increased in western Nebraska in order to conserve soil moisture. This technique often allows a better opportunity for pathogen survival in infested residue, thereby potentially posing an elevated risk for infecting subsequent wheat or dry bean crops.

\section{LITERATURE CITED}

Ellis, M. L., Broders, K. D., Paul, P. A., and Dorrance, A. E. 2011. Infection of soybean seed by Fusarium graminearum and effect of seed treatments on disease under controlled conditions. Plant Dis. 95:401-407.

Galkiewicz, J. P., and Kellog, C. A. 2008. Cross-kingdom amplification using bacteria-specific primers: Complications for studies of coral microbial ecology. Appl. Environ. Microbiol. 74:7828-7831.

Hsieh, T-F., Huang, H-C., and Erickson, R. S. 2010. Spread of seed-borne Erwinia rhapontici in bean, pea and wheat. Eur. J. Plant Pathol. 127:579584.

Huang, H-C., Erickson, R. S., and Hsieth, T. F. 2007. Lack of host specificity of strains of Erwinia rhapontici causal agent of pink seed of pulse and cereal crops. Bot. Stud. 48:181-186.

Huang, H-C., Hsieth, T. F., and Erickson, R. S. 2003. Biology and epidemiology of Erwinin rhapontici, causal agent of pink seed and crown rot of plants. Plant Pathol. Bull. 12:69-76.

Jasa, L. 2013. Panhandle Growers, Co-op Developing Yellow Field Peas as a New Crop. CropWatch 5/10/2013 ed. University of Nebraska-Lincoln.

Wise, K. A., Zhao, Y. F., and Bradley, C. A. 2008. First report of pink seed of pea caused by Erwinia rhapontici in North Dakota. Plant Dis. 92:315. 